Prismatika: Jurnal Pendidikan dan Riset Matematika Vol. 3 No. 1 (2020)

p-ISSN: 2654-6140, e-ISSN: 2656-4181

http://ejurnal.budiutomomalang.ac.id/index.php/prismatika

\title{
PENERAPAN MONTESSORI DALAM PEMBELAJARAN MATEMATIKA MELALUI LURING SEBAGAI ALTERNATIF MASA PANDEMI
}

\author{
Sulha \\ SD Negeri Karengren 1 Kabupaten Probolinggo \\ sulhabasuki@gmail.com
}

\begin{abstract}
Abstrak
Covid-19 yang melanda seluruh pelosok negeri menjadikan pemangku kebijakan pendidikan harus mengubah model pembelajaran dengan menerapkan protokol kesehatan, salah satunya yang disebut dengan pembelajaran luring. Montessori merupakan pembelajaran yang terkonsep sesuai dengan aktivitas sehari-hari yang dialami langsung oleh siswa. Tujuan dari penelitian ini adalah mendeskripsikan penerapan Montessori pada pembelajaran matematika melalui luring. Metode penelitian yang digunakan adalah kualitatif yang dipaparkan secara deskritif. Subjek dari penelitian adalah siswa kelas II SD Negeri Karangren 1 pada semester 1 tahun pelajaran 2020/2021. Hasil penelitian menunjukkan bahwa diperlukan dukungan lingkungan yang baik demi menunjang metode montessori dalam luring pembelajaran matematika. Dukungan tersebut diantaranya adalah ketersediaannya aparatus Montessori serta kemauan orang tua untuk mendukung pembelajaran.
\end{abstract}

Kata kunci: montessori, luring, matematika SD

\begin{abstract}
Covid-19, which has hit all corners of the country, has made education policymakers to change the learning model by implementing health protocols, one of which is called offline learning. Montessori is a learning concept in accordance with daily activities that are experienced directly by students. This study aimed to describe the application of montessori in offline mathematics learning. The research method used qualitative descriptively. The subjects of the study were second-grade students of SD Negeri Karangren 1 in the 1 st semester of the 2020/2021 school year. The results showed that good environmental support was needed to support the montessori methods in offline mathematics learning. This support includes the availability of the montessori apparatus and the willingness of parents to support learning.
\end{abstract}

Keywords: montesori, offline, elementary school mathematics 
Sulha

Penerapan Montessori dalam Pembelajaran Matematika Melalui Luring sebagai Alternatif Masa Pandemi

\section{PENDAHULUAN}

Corona Virus Disease 2019 (Covid-19) yang mewabah mengakibatkan sekolah tidak diperkenankan untuk melakukan pembelajaran tatap muka. Penutupan sekolah menjadi langkah mitigasi paling efektif untuk meminimalisir penyebaran wabah pada anak-anak (Herliandry, Nurhasanah, Suban, \& Heru, 2020). Setelah melalui kebijakan School From Home, maka memasuki era new normal, kebijakan yang diberikan oleh kementerian pendidikan adalah dengan melakukan pembelajaran dalam jaringan (daring), luar jaringan (luring), atau masuk secara bergantian (shift).

Shift dilakukan guna mengikuti protokol kesehatan demi menghindari kegiatan berkerumun. Dengan melakukan pembelajaran secara shift maka sosial distancing dan physical distancing akan lebih mudah diterapkan. Shift merupakan pembelajaran tatap muka di sekolah yang hanya boleh dilakukan bagi sekolah yang berada dalam zona hijau atau kuning. Probolinggo merupakan sebuah kabupaten yang terletak di Jawa Timur dengan zona merah atau oranye. Hingga waktu penelitian ini dilakukan, tidak pernah berwarna hijau atau kuning. Gugus tugas Satgas Covid-19 menyatakan bahwa pembelajaran bagi siswa SD di Kabupaten Probolinggo tidak boleh dilaksanakan dengan tatap muka di sekolah.

Padahal, di Kecamatan Krejengan Kabupaten Probolinggo sangat minim signal (jaringan). Pembelajaran daring sulit dilakukan. Pelaksanaan pembelajaran daring bergantung pada kondisi bagus tidaknya jaringan. Jika jaringan tidak cukup, maka akan mengakibatkan siswa ketinggalan materi karena tidak tepat waktu mengikuti kegiatan pembelajaran (Yensy, 2020). Tidak hanya terkendala oleh jaringan, tetapi juga ketersediaan gadget dari para orang tua wali murid. Lebih dari separuh siswa tidak dapat melakukan pembelajaran dengan sistem daring karena orang tuanya tidak memiliki gadget. Gadget menjadi faktor pendukung utama dalam pembelajaran daring karena tanpa adanya gadget pembelajaran daring tidak akan terlaksana (Putria, Maulana, \& Uswatun, 2020).

Dengan memperhatikan kondisi tersebut, maka pilihan yang bisa ditempuh oleh sekolah adalah dengan melakukan pembelajaran luring. Guru akan mendatangi rumah-rumah siswa secara bergantian untuk melakukan pembelajaran. Guru akan hadir dalam door to door pada siswa. Guru bukan hanya memposisikan sebagai pentransfer ilmu, tetapi tetap saja mengutamakan ing ngarso sung tulada, ing madya mangun karsa, tut wuri handayani (Aji, 2020).

SD Negeri Karangren I adalah sekolah yang terletak di Desa Karangren 1, Kecamatan Krejengan, Kabupaten Probolinggo. Siswa di SD Negeri Karangren 1 berasal dari tiga dusun, diantaranya adalah Dusun Sukun, Dusun 
Sulha

Penerapan Montessori dalam Pembelajaran Matematika Melalui Luring sebagai Alternatif Masa Pandemi

Sumbermendo, dan Dusun Krajan. Hambatan pun kembali dihadapi. Karena dengan melakukan pembelajaran luring, guru hanya bisa menjangkau dua hingga tiga siswa saja dalam sehari. Hal ini menyebabkan guru dapat bertemu dengan masing-masing siswa hanya seminggu satu kali dengan jam yang juga terbatas.

Berdasarkan latar belakang yang disebutkan di atas, tentu bukan perkara mudah untuk melakukan pembelajaran yang efektif. Sebisa mungkin, guru harus melakukan cara-cara agar dalam pertemuan yang singkat itu dapat berkualitas dan pada hari-hari lainnya siswa tetap dapat belajar meski tidak bertatap muka dengan guru secara langsung. Maka di sini, alternatif yang digunakan peneliti adalah dengan menerapkan pembelajaran montessori. Pembelajaran montessori merupakan sebuah metode belajar dengan melakukan praktik langsung terhadap lingkungan sekitar (Cipta, Avianty, \& Kurniawati, 2019b)

Berbeda dengan metode pembelajaran lain yang banyak menggunakan interaksi dengan guru, menjadikan guru atau buku-buku sebagai sumber belajar, metode Montessori menguatkan interaksi dengan lingkungan sebagai sumber belajar. Pembelajaran langsung dihadapkan pada kebiasaan dan aktivitas sehari-hari, serta dapat memilih materi pembelajaran berdasarkan keinginan dan kebutuhan siswa.

Berdasarkan uraian tersebut, dirumuskan suatu masalah penelitian. Rumusan masalah pada penelitian ini adalah bagaimana metode montessori diterapkan dalam pembelajaran luring siswa kelas II SD Negeri Karangren 1 pada semester satu tahun pembelajaran 2020/2021 pada masa pandemi Covid-19.

\section{METODE PENELITIAN}

Penelitian yang digunakan adalah metode kualitatif dengan pemaparan secara deskriptif. (Sugiyono, 2016)menyebutkan penelitian kualitatif merupakan metode penelitian yang berlandaskan pada filsafat postpositivme yang digunakan untuk meneliti kondisi obyek alamiah, dimana peneliti sebagai instrumen kunci.Pengambilan sampel sumber data dilakukan secara purposive dan snowball, teknik pengumpulan dengan triangulasi (gabungan), analisis data bersifat induktif/kualitatif, dan hasil penelitian lebih menekankan makna dari pada generalisasi.

Subjek pada penelitian ini adalah siswa kelas II SD Negeri Karangren 1 sejumlah 19 anak. Penelitian dilaksanakan pada tanggal 3 - 22 Agustus 2020. Penerapan montessori dilakukan pada Tema 1 yaitu Hidup Rukun yang melingkup seluruh mata pelajaran. Namun, fokus dalam penelitian ini hanyalah pada pelajaran matematika saja yang membahas tentang Nilai 
Sulha

Penerapan Montessori dalam Pembelajaran Matematika Melalui Luring sebagai Alternatif Masa Pandemi

Tempat Suatu Bilangan.Peneliti adalah kepala sekolah yang dalam hal ini sengaja melakukan pembelajaran luring karena pembelajaran daring yang dilakukan guru kelas II dirasa tidak cukup untuk menggantikan pembelajaran di kelas yang ditiadakan selama masa pandemi Covid-19.

Penelitian ini akan memaparkan bagaimana metode montessori tersebut diterapkan pada materi Nilai Tempat Suatu Bilangan. Diawali dengan menyiapkan instrumen pembelajaran berupa skenario pembelajaran yang telah divalidasi oleh dua profesional yaitu guru kelas II dan guru Matematika. Pembelajaran diterapkan dengan luring, guru akan mendatangi rumah-rumah siswa untuk melaksanakan pembelajaran. Dengan menggunakan metode montessori, pertemuan luring ini diisi dengan diskusi. Sementara di luar pertemuan, guru akan meninggalkan penugasan berupa proyek. Penugasan mengikuti metode montessori yang melibatkan lingkungan sekitar sebagai sumber belajar. Pada akhir penelitian, akan diberikan tes ulangan siswa untuk melihat hasil belajar. Sepanjang penelitian berlangsung, peneliti melakukan wawancara tidak terstruktur digunakan untuk melihat bagaimana tanggapan siswa terhadap metode pembelajaran montessori, serta pengamatan sebagai penguat dari wawancara dan tes untuk kemudian dianalisis dengan metode kualitatif.

\section{HASIL DAN PEMBAHASAN}

Pandemi Covid-19 mengharuskan siswa SD Negeri Karangren 1 Kecamatan Krejengan Kabupaten Probolinggo melakukan kegiatan sekolah di rumah. Selain melalui pembelajaran secara daring yang tidak efektif, guru akan datang seminggu sekali pada masing-masing rumah siswa untuk memberikan pembelajaran secara langsung. Kegiatan pembelajaran yang disebut dengan luring ini mengikuti protokol percepatan penanggulangan penyebaran Covid-19.

Jika pada pelaksanaan pembelajaran yang dilakukan di sekolah telah banyak ditemukan metode pembelajaran yang efektif, maka pada pembelajaran luring ini masih terus perlu dilakukan pengkajian dan penelitian agar dapat diterapkan seefektif mungkin. Guru harus mngerti bagaimana caranya agar dalam pertemuan yang singkat itu dapat memberikan energi dan suntikan pembelajaran untuk kemudian dilakukan oleh siswa dalam seminggu mendatang.

Guru dan siswa memiliki keterbatasan waktu pembelajaran, sementara siswa akan lebih banyak bersama lingkungan di rumah. Maka, tentu pembelajaran yang tepat dan efektif untuk dikembangkan dalam luring adalah kegiatan pembelajaran yang banyak melibatkan lingkungan sebagai tempat belajar. 
Sulha

Penerapan Montessori dalam Pembelajaran Matematika Melalui Luring sebagai Alternatif Masa Pandemi

Montessori merupakan sebuah model pembelajaran yang diusung oleh Maria Montessori. Pada Montessori, siswalah yang menguasai panggung kelas dengan lingkungan sebagai titik pusat kegiatan belajarnya (Cipta, 2018). Artinya, siswa akan memanfaatkan lingkungan sebagai tempat belajar. Segala sesuatu yang ada di sekitarnya akan dijadikan sebagai objek belajar.

Merujuk pada montessori, maka dalam luring ini peneliti akan memberikan pembelajaran yang kemudian dapat dilakukan oleh siswa pada hari-hari berikutnya dalam satu minggu ke depan. Pada pembelajaran Matematika kelas 2 SD Tema 1 adalah mengenai Nilai Tempat Suatu Bilangan dengan Tema Hidup Rukun di Rumah. Tema yang tepat sesuai dengan School From Home.

Montessori pada penerapan pembelajaran dalam penelitian ini dimulai dari pengenalan terhadap jumlah benda yang kemudian memberikan worksheet berupa isian yang harus dikerjakan oleh siswa di luar jadwal luring. Worksheet tersebut berisi pertanyaan-pertanyaan tentang jumlah benda di dalam rumah. Misalnya, berapa jumlah kursi, berapa jumlah meja, jumlah gelas, piring, dan sendok yang ada di rumah. Hal ini sejalan dengan pernyataan Amalina (2020)bahwa "Pembelajaran angka dan pengenalan konsep bilangan dapat dilakukan dengan menghitung jumlah benda yang ada pada ruang tamu seperti kursi, meja, lemari dan sekaligus mengenalkan kosep besar-kecil, jauh-dekat, tinggi-rendah". Yang lebih sederhana lagi dapat menghitung langkah ketika masuk kedalam kamar, hal sederhana tersebut menjadikan matematika merupakan bagian dari aktivitas keseharian anak dirumah (Fitria, 2013).

Pola pikir siswa sekolah dasar masih konkret. Ia belum bisa berpikir secara abstrak. Maka agar ia tidak terjebak dalam mengerjakan matematika tanpa logika, pembelajaran matematika harus disajikan sekonkret mungkin, sesuai dengan pola berpikirnya (Cipta, Avianty, \& Kurniawati, 2019a). Montessori yang menghadapkan langsung pada lingkungan sekitar menjadikan siswa berpikir benar-benar konkret. Mereka akan melakukan perhitungan secara nyata. Menghitung benda yang sesungguhnya yang ada di sekitar mereka.

Selanjutnya, beranjak pada pemaparan mengenai nilai tempat, siswa akan dikenalkan pada beberapa benda yang bisa difungsikan untuk mengenalkan nilai satuan, puluhan, dan ratusan. Belajar mengenai konsep dan struktur materi matematika dimulai dengan pengenalan masalah secara kontekstual. Dengan mengajukan masalah secara kontekstual, siswa akan dibimbing secara bertahap untuk menguasai konsep dalam matematika (Wiryanto, 2020). Beberapa benda di lingkungan sekitar yang dapat difungsikan untuk pembelajaran ini adalah sedotan, maupun rangkaian manik-manik seperti woorksheet berikut ini. 
Sulha

Penerapan Montessori dalam Pembelajaran Matematika Melalui Luring sebagai Alternatif Masa Pandemi

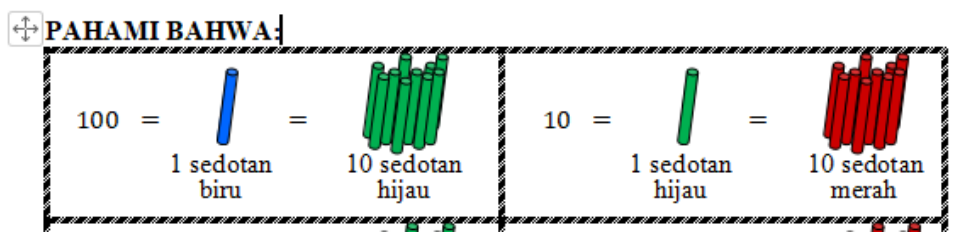

Gambar 1. Pembelajaran yang Diberikan Saat Bertemu

Setelah belajar bersama, guru akan meninggalkan sedotan untuk digunakan siswa mengerjakan worksheet berikutnya, seperti menentukan nilai suatu bilangan berdasarkan sedotan yang telah disusun oleh siswa.

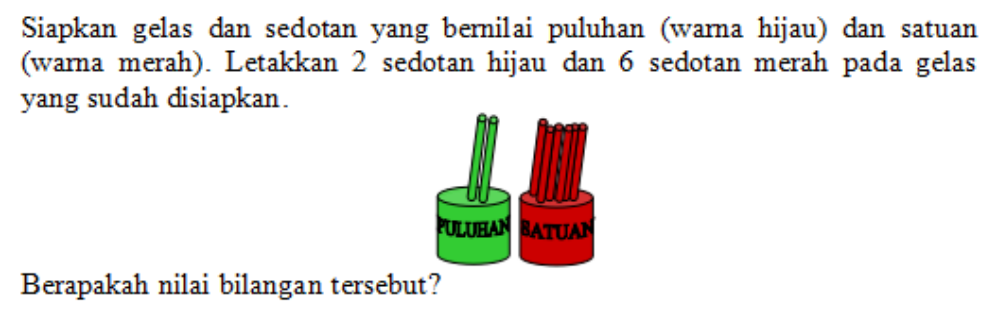

Gambar 2. Penugasan Siswa

Tidak hanya berhenti pada nilai suatu bilangan, pembelajaran dapat dikembangkan pada penjumlahan dan pengurangan. Siswa akan melakukan sendiri, bagaimana dia dapat memanfaatkan sedotan dan gelas-gelas tersebut. Pembelajaran bilangan yang dianggap susah, jika guru dapat mengemasnya dengan cara yang menyenangkan, tentu akan dapat lebih mudah dipahami oleh siswa (Kurniawan, 2020).

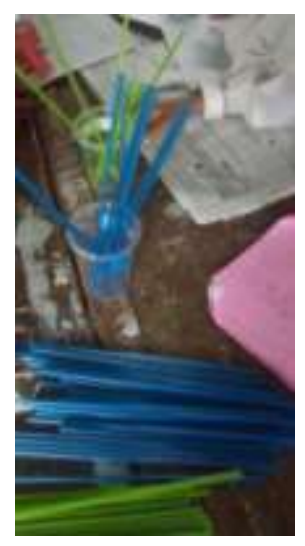

\section{Gambar 3. Siswa Menyusun Sedotan di Gelas}

Selanjutnyam tidak hanya terpaku pada sedotan, pembelajaran dapat dikembangkan dengan menggunakan barang-barang yang ada di sekitar yang 
Sulha

Penerapan Montessori dalam Pembelajaran Matematika Melalui Luring sebagai Alternatif Masa Pandemi

banyak ditemui oleh siswa. Penggunaan media yang dilibatkan dalam pembelajaran montessori juga dibenarkan oleh penelitian Sugita (2014) yang menunjukkan bahwa penggunaan alat peraga berupa kelereng dan batu kerikil dapat meningkatkan kemampuan perkalian siswa kelas II sekolah dasar.

Berdasarkan hasil wawancara tidak terstruktur yang dilakukan oleh peneliti, didapati bahwa siswa sangat menyenangi pembelajaran montessori ini. Siswa menjadi tidak bosan karena dapat bermain sambil belajar. Hal ini kemudian ditunjang dengan hasil belajar siswa yang mengalami peningkatan lebih baik. Salah satu faktor yang mempengaruhi peningkatan hasil belajar siswa dalah metode pembelajaran yang menarik dan memacu keakifan siswa dalam proses pembelajaran (Mustafa, 2018).

Sedangkan dari hasil tes siswa berupa ulangan Nilai Tempat Suatu Bilangan, hasil yang didapati telah memenuhi KKM. Siswa telah dapat menentukan nilai tempat suatu bilangan, mengenal bilangan satuan, puluhan, dan ratusan. Dari hasil ulangan ini, didapati nilai siswa lebih bagus dibanding menggunakan metode sebelumnya. Siswa memahami konsep nilai tempat suatu bilangan secara baik.

Pembelajaran montessori sangat mudah diterapkan oleh siswa selama masa pandemi ini. Selain mudah dipelajari, benda konkret ini juga mudah diperoleh di sekitar kita, siswa juga dapat membuatnya sendiri dirumah. Jadi siswa tidak merasa asing jika kita menggunakan media pembelajaran benda konkret ini untuk membantu siswa dalam belajar matematika (Sulistiani, 2016).

Namun demikian, keberhasilan penerapan montessori dalam pembelajaran luring ini juga ditentukan oleh dukungan dari orang tua. Dalam penelitian ditemukan bahwa ada siswa yang tidak dapat mengerjakan dengan baik, misalnya dalam menghitung gelas yang ada di rumah, karena tidak diizinkan oleh orang tua. Orang tua menganggap bahwa aktivitas yang dilakukan oleh siswa sangat merepotkan dan membuat berantakan. Jika hal tersebut terjadi, maka tentu siswa tidak dapat mengerjakan worksheet secara baik.

\section{KESIMPULAN DAN SARAN}

Pandemi covid-19 yang melanda negeri ini membuat guru harus menemukan metode yang tepat untuk mengatasi keterbatasan. Baik keterbatasan jaringan, gadget, maupun pertemuan yang sangat singkat dengan siswa. Demi mematuhi protokol kesehatan dalam percepatan penanggulangan penyebaran Covid-19 maka penerapan montessori dengan pembelajaran luring dapat menjadi alternatif untuk mengajarkan 
Sulha

Penerapan Montessori dalam Pembelajaran Matematika Melalui Luring sebagai Alternatif Masa Pandemi

matematika. Pada penelitian yang dilakukan kelas II SD Negeri Karangren I Kecamatan Krejengan Kabupaten Probolinggo, pembelajaran luring dengan montessori pada materi Mengenal Nilai Tempat Suatu Bilangan dalam Tema Hidup Rukun di Rumah dinilai sangat efektif.

Keberhasilan penerapan pembelajaran ini sangat bergantung pada dukungan orang tua. Untuk itu, sangat penting dilakukan edukasi kepada orang tua guna mendukung kegiatan belajar siswa.

\section{DAFTAR RUJUKAN}

Aji, R. H. S. (2020). Dampak Covid-19 pada Pendidikan di Indonesia: Sekolah, Keterampilan, dan Proses Pengajaran. Salam: Jurnal Sosial Dan Budaya Syar'i, 7(5), 395-402.

Amalina, A. (2020). Pembelajaran Matematika Anak Usia Dini di Masa Pandemi COVID-19 Tahun 2020. Jurnal Obsesi : Jurnal Pendidikan Anak Usia Dini, 5(1). https://doi.org/10.31004/obsesi.v5i1.592

Cipta, D. A. S. (2018). Penerapan Pendekatan Montessori untuk Menanamkan Pemahaman Konsep Bilangan Cacah pada Siswa TK Putera Zaman Malang. Matematika Dan Pembelajaran, 6(1). https://doi.org/10.33477/mp.v6i1.440

Cipta, D. A. S., Avianty, D., \& Kurniawati, A. (2019a). Profil Berpikir Kritis Siswa Asperger pada Pembelajaran Bangun Datar dengan Metode Montessori. Jurnal Didaktik Matematika, 6(2). https://doi.org/10.24815/jdm.v6i2.14175

Cipta, D. A. S., Avianty, D., \& Kurniawati, A. (2019b). Three Period Lesson pada Matematika Montessori untuk Siswa Penyintas Autisme. In Seminar Nasional Pendidikan Matematika 2019. Malang: Universitas Muhammadiyah.

Fitria, A. (2013). Mengenalkan dan Membelajarkan Matematika Pada Anak Usia Dini. Jurnal Studi Gender Dan Anak, 1(2).

Herliandry, L. D., Nurhasanah, Suban, M. E., \& Heru, K. (2020). Pembelajaran Pada Masa Pandemi Covid-19. Jurnal Teknologi Pendidikan, 22(1).

Kurniawan, C. (2020). Menumbuhkan Rasa Senang Berhitung dengan Metode Jarimatika pada Siswa TK. Prismatika: Jurnal Pendidikan Dan Riset Matematika, 2(2). https://doi.org/10.33503/prismatika.v2i2.690

Mustafa, M. B. (2018). Peningkatan Hasil Belajar Matematika Siswa Kelas II SD Melalui Model Pembelajaran Kooperatif Tipe Student Team Achievement Division. Jurnal Cendekia : Jurnal Pendidikan Matematika, 2(2). https://doi.org/10.31004/cendekia.v2i2.55

Putria, H., Maulana, L., \& Uswatun, D. (2020). Analisis Proses Pembelajaran Dalam Jaringan (DARING) MasaPandemi COVID-19 pada Guru Sekolah 
Sulha

Penerapan Montessori dalam Pembelajaran Matematika Melalui Luring sebagai Alternatif Masa Pandemi

Dasar. Jurnal Basicedu: Research \& Learning in Elementary Education, 4(4), 861-872.

Sugita. (2014). Meningkatkan Kemampuan Perkalian Siswa Kelas 2 SDN 003 Rantau Pulung Menggunakan Alat Peraga Kelereng dan Batu Kerikil. Dinamika Ilmu, 14(2), 214-224.

Sugiyono, P. D. Metode Penelitian Kuantitatif, Kualitatif,dan R\&D, Alfabeta, cv. (2016).

Sulistiani, I. R. (2016). Pembelajaran Matematika Materi Perkalian dengan Menggunakan Media Benda Konkret (Manik-manik dan Sedotan) untuk Meningkatkan Hasil Belajar. VICRATINA : Jurnal Kependidikan Dan Keislaman, 10(2).

Wiryanto. (2020). Proses Pembelajaran Matematika di Sekolah Dasar di Tengah Pandemi Covid-19. Jurnal Review Pendidikan Dasar, 6(2).

Yensy, N. A. (2020). Efektifitas Pembelajaran Statistika Matematika melalui Media Whatsapp Group Ditinjau dari Hasil Belajar Mahasiswa (Masa Pandemik Covid 19). Jurnal Pendidikan Matematika Raflesia (Vol. 5). 